\title{
Anorexígenos e fosfoetanolamina sintética: a lição que não foi aprendida
}

Anorexigenics and synthetic phosphoethanolamine: the lesson that was not learned

Anorexígenos y fosfoetanolamina sintética: la lección que no se ha aprendido

\section{Sandra Mara Campos Alves ${ }^{1}$} Ivan Pricken de Bem²

Uma vez mais, o conhecimento científico e a proteção à saúde são abandonados para fazer valer interesses de uma agenda oculta. Ao completo arrepio do arcabouço normativo (1) (2) (3) (4) que busca proteger a saúde da população brasileira foi sancionada a Lei ํo 13.454 (5) que autoriza a produção, comercialização e o consumo de inibidores de apetite (sibutramina, anfepramona, femproporex e mazindol), sem que haja a necessidade de aprovação do produto pela Agência Nacional de Vigilância Sanitária - Anvisa

Trata-se de batalha antiga travada entre prescritores, indústria farmacêutica e a Anvisa e que agora ultrapassou a barreira da regulação sanitária para encontrar guarida no Poder Legislativo, que ignorando cláusula pétrea do princípio da separação de poderes, derrogou a competência da referida agência reguladora e tratou, ele próprio, de autorizar a produção e comercialização dos anorexígenos, ainda que não comprovada a segurança e eficácia dos produtos.

O caso não difere do que aconteceu em um passado recente, quando o Poder Legislativo aprovou a Lei no 13.269/2016 (6) que autorizou a produção e comercialização da fosfoetanolamina sintética (7).

No caso específico dos anorexígenos, houve manifestação contrária a aprovação do Projeto de Lei no 2431/2011 pela Anvisa e pela Advocacia Geral da União. Esta última, no parecer ํㅜ 572/2017-Conjur-MS/CGU/AGU (8) se pronunciou pelo veto

\footnotetext{
${ }^{1}$ Advogada, Mestre em Política Social e pesquisadora colaboradora do Programa de Direito Sanitário da Fundação Oswaldo Cruz em Brasília.

2 Bacharel em Gestão em Saúde Coletiva pela Universidade de Brasília (UnB). Especialista em Direito Sanitário pela Fundação Oswaldo Cruz. Pesquisador Colaborador no Programa de Direito Sanitário da FIOCRUZ. Brasília, DF, Brasil. E-mail: ivanprk@gmail.com.
} 
integral ao projeto de lei, apontando a existência de inconstitucionalidade material por violação ao princípio da separação dos poderes e por afrontar o direito à saúde.

Sobre o princípio, o filósofo iluminista Montesquieu já afirmava que "tudo estaria perdido se o mesmo homem ou o mesmo corpo dos principais ou dos nobres, ou do povo, exercesse esses três poderes: o de fazer as leis, o de executar as resoluções públicas e o de julgar os crimes ou as divergências dos indivíduos" (9).

No caso concreto, observamos uma dupla invasão dessa separação. Primeiramente porque o Poder Legislativo, por meio de uma inovação na ordem jurídica, afastou todo um arcabouço legal regulatório já consolidado, derrogando inclusive a competência da Anvisa para atuar na vigilância sanitária de medicamentos. Não satisfeito com tamanha invasão, aproveitou uma "janela de oportunidade" para, ele mesmo, imbuído das vestimentas de chefe do executivo, sancionar a matéria, visto que o chefe do Poder Executivo estava em viagem oficial ao exterior, estando temporariamente impossibilitado da prática de atos inerentes a função.

Ora, a divergência de opiniões e a prudência necessária para atuar em matéria tão delicada como a saúde, orientariam aguardar o retorno do titular do cargo do executivo de afastamento temporário, para decidir sobre a sanção ou veto do projeto de lei, oportunidade em que o princípio da separação dos poderes seria melhor observado. Todavia, o que se observou foi um atropelo aos princípios e normas jurídicas, e total desconsideração à segurança da saúde da população que irá consumir tais medicamentos.

Ressalte-se que apesar do texto legal ter reconhecido implicitamente que se trata de medicamento que contém substância psicotrópica, vez que exige a prescrição em receituário médico de modelo $\mathrm{B} 2$, não observou a cautela relacionada a esse tipo de produto no que tange a aprovação pelo órgão regulatório de sua segurança e eficácia.

No caso da fosfoetanolamina, o Supremo Tribunal Federal, de forma acauteladora, decidiu pela suspensão da eficácia da lei, por julgar temerária e danosa a liberação do uso e comercialização de produto que não apresentava evidência científicas sobre os resultados positivos para a saúde dos usuários da substância (10), mas parece que a lição não foi aprendida, visto que o país depara, novamente, com tamanha aberração legislativa. 
Resta agora aguardar que um dos atores elencados no texto constitucional como aptos a propor a Ação Direta de Inconstitucionalidade ingressem de modo imediato no Poder Judiciário para restabelecer a ordem jurídica e o dever estatal de proteger a saúde da população.

\section{REFERÊNCIAS}

1. Brasil. Constituição da República Federativa do Brasil de 1988. Disponível em: http://www.planalto.gov.br/ccivil_03/constituicao/constituicao.htm [Acesso em 27. jun. 2017].

2. Brasil. Lei 6360 , de 23 de setembro de 1976. Dispõe sobre a vigilância sanitária a que ficam sujeitos os medicamentos, as drogas, os insumos farmacêuticos e correlatos, cosméticos, saneantes e outros produtos, e dá outras providências. Disponível em: http://www.planalto.gov.br/ccivil_03/leis/l6360.htm [Acesso em 27. jun. 2017].

3. Brasil. Lei 5991 de 17 de dezembro de 1973. Dispõe sobre o controle sanitário do comércio de drogas, medicamentos, insumos farmacêuticos e correlatos e dá outras providências. Disponível em: http://www.planalto.gov.br/ccivil_03/leis/L5991.htm [Acesso em 27. jun. 2017].

4. Brasil. Lei 9782 de 26 de janeiro de 1999. Define o Sistema Nacional de Vigilância Sanitária, cria a Agência Nacional de Vigilância Sanitária, e dá outras providências. Disponível em: http://www.planalto.gov.br/ccivil_03/leis/L9782.htm [Acesso em 27 jun. 2017].

5. Brasil. Lei 13.454 de 23 de junho de 2017. Autoriza a produção, a comercialização e o consumo, sob prescrição médica, dos anorexígenos sibutramina, anfepramona, femproporex e mazindol. Disponível em: http://www.planalto.gov.br/ccivil_03/_ato20152018/2017/lei/L13454.htm [Acesso em 27 jun. 2017]

6. Brasil. Lei 13.269, de 13 de abril de 2016. Autoriza o uso da fosfoetanolamina sintética por pacientes diagnosticados com neoplasia maligna. Disponível em: http://www.planalto.gov.br/ccivil_03/_Ato2015-2018/2016/Lei/L13269.htm [Acesso em 15 abr. 2017].

7. Alves SMC, Delduque MC, Santos AO. Lei no 13.269/2016: a comoção da sociedade vence o método científico! Cad. Saúde Pública 2016; 32: 1-2. Disponível em: http://www.scielo.br/pdf/csp/v32n6/1678-4464-csp-32-06-e00070116.pdf [Acesso em 27. jun. 2017]

8. Brasil. Advocacia Geral da União. Parecer nº 572/2017/CONJUR-MS/CGU/AGU.

Disponível em: 
http://portal.anvisa.gov.br/documents/219201/2782895/Parecer+anorex\%C3\%ADgenos/ 00ef6b41-4562-4df4-8f70-1238ddd54930 [Acesso em 24 jun. 2017)

9. Montesquieu CS. O espírito das leis. São Paulo: Martins Fontes, 1993, p. 181.

10. Supremo Tribunal Federal. Ação Direta de Inconstitucionalidade $\mathrm{n}^{\circ} 5.501$ de 2016. Disponível em:

http://www.stf.jus.br/arquivo/cms/noticiaNoticiaStf/anexo/adi5501MMA.pdf [Acesso em 27 jun. 2017]

Recebido em 19.9.2017

Aprovado em: 8.12.2017

\section{Como citar este artigo:}

Alves SMC, Bem IP. Anorexígenos e fosfoetanolamina sintética: a lição que não foi aprendida. Revista Cadernos Ibero-Americanos de Direito Sanitário. 2017 out./dez, 6(4):180-183. 